Плодоводство и виноградарство Юга России № 60(6), 2019 г.

УДК 663.2

DOI 10.30679/2219-5335-2019-6-60-163-171

ИССЛЕДОВАНИЕ ВЛИЯНИЯ СПОСОБА ПРЕДВАРИТЕЛЬНОЙ ОБРАБОТКИ НА СТРУКТУРНЫЕ СВОЙСТВА ДРЕВЕСИНЫ ДУБА В КОНЬЯЧНОМ ПРОИЗВОДСТВЕ

Резниченко Кристина Вячеславовна канд. техн. наук научный сотрудник

НЦ «Виноделие» e-mail: kokoko20@list.ru

Антоненко Михаил Викторович канд. техн. наук старший научный сотрудник НЦ «Виноделие» e-mail: antonenko84@bk.ru

Алейникова Галина Юрьевна канд. с.-х. наук

ст. научный сотрудник

зав. лаборатории управления воспроизводством в ампелоценозах

и экосистемах

e-mail: gala.aleynikova@gmail.ru

Антоненко Ольга Павловна

канд. техн. наук

научный сотрудник

НЦ «Виноделие»

e-mail: pastarnakova@bk.ru

Глоба Екатерина Владимировна младший научный сотрудник НЦ «Виноделие» e-mail: balandina119@mail.ru

Федеральное государственное бюджетное научное учреждение «Северо-Кавказский федеральный научный иентр садоводства, виноградарства, виноделия», Краснодар, Россия

Повышение качества и улучшение органолептических показателей коньяка при его производстве достигается главным образом за счет экстрагирования компонентов древесины дуба,
UDC 663.2

DOI 10.30679/2219-5335-2019-6-60-163-171

\section{STUDY OF THE INFLUENCE THE PRETREATMENT METHOD THE STRUCTURAL PROPERTIES OF OAK WOOD IN THE COGNAC PRODUCTION}

Reznichenko Kristina Vyacheslavovna

Cand. Tech. Sci.

Research Associate

of SC «Winemaking»

e-mail: kokoko20@list.ru

Antonenko Mikhail Viktorovich

Cand. Tech. Sci.

Senior Research Associate

of SC «Winemaking»

e-mail: antonenko84@bk.ru

Aleynikova Galina Yur'evna

Cand. Agr. Sci.

Senior Research Associate

Head of Laboratory of Reproduction

in the Ampelocenoses

and Ecological Systems

e-mail: gala.aleynikova@gmail.ru

Antonenko Ol'ga Pavlovna

Cand. Tech. Sci.

Research Associate

of SC «Winemaking»

e-mail: pastarnakova@bk.ru

Globa Ekaterina Vladimirovna

Junior Research Associate

of SC «Winemaking»

e-mail: balandina119@mail.ru

Federal State

Budget Scientific Institution

«North Caucasian Federal

Scientific Center of Horticulture,

Viticulture, Wine-making»,

Krasnodar, Russia

Quality improvement and improvement of organoleptic characteristics of cognac in its production is achieved mainly due to the extraction of oak wood components, their transformation

\footnotetext{
* Исследование выполнено при финансовой поддержке РФФИ и Администрации Краснодарского края в рамках научного проекта № 19-416-233021
} 
их трансформации до ароматических альдегидов и дубильных веществ, накопления их в выдерживаемом коньячном дистилляте в оптимальных концентрациях. Способ подготовки древесины дуба является важным технологическим приёмом, имеющим большое влияние на качество коньяка. При обработке древесины происходит растворение определённой части компонентов клеточных стенок, которое приводит к увеличению объёма полостей клеток, и, как следствие, к увеличению пористости. Повышение пористости и увеличение проницаемости клеточной стенки волокон древесины обеспечивает более полное извлечение лигнина, дубильных веществ и ароматических альдегидов дистиллятом в процессе выдержки коньячного дистиллята. При этом, соответственно, изменяются механические свойства древесины. В статье представлены результаты Исследований изменения адсорбционной Ёмкости (пористости) дубовой древесины при различных способах её активации: кислотной, щелочной, термической и биохимической. Установлено, что к наиболее сильным изменениям структуры древесины дуба приводит щелочная обработка, за счёт увеличения её адсорбционной ёмкости (пористости) в 4,7-5,6 раза. При термической обработке дубовой древесины величина адсорбции на её поверхности увеличивается в 4,4 раза, а при биохимической - в 2,4-3,7 раза по сравнению с таковой у необработанной древесины. Кислотная обработка древесины дуба характеризовалась самой низкой величиной адсорбции среди всех рассматриваемых способов обработки, увеличивая показатель адсорбции всего в 2,2-3 раза.

Ключевые слова: ДРЕВЕСИНА ДУБА, ПРЕДВАРИТЕЛЬНАЯ ОБРАБОТКА, ПОРИСТОСТ, КОНЬЯК to aromatic aldehydes and tannins and their accumulation in the mature cognac distillate in optimal concentrations. The method of preparation of oak wood is an important technological technique that has a great impact the quality of cognac. When processing the wood, the dissolution of some of the components of the cell walls occurs, which leads to an increase in the volume of cell cavities, and, as a consequence, to an increase in porosity. Increased porosity and increased permeability of the cell wall of wood fibers provides a more complete extraction of lignin, tannins and aromatic aldehydes by distillate in the mature process of cognac distillation. At the same time, respectively, the mechanical properties of wood are changed. The article presents the results of studies of changes in the adsorption capacity (porosity) of oak wood using the different ways of its activation: acid, alkaline, thermal and biochemical activation.

It is established that alkaline treatment leads to the strongest changes in the structure of oak wood, by increasing the adsorption capacity (porosity) by 4,7-5,6 times. In the process of heat treatment of oak wood the value of adsorption on its surface increases in 4,4 times, and at biochemical treatment - in 2,4-3,7 times in comparison with untreated wood. Acid treatment of oak wood was characterized by the lowest adsorption value among all the considered ways of treatments, increasing in the adsorption value by only 2,2-3 times.

Key words: OAK WOOD, PRELIMINARY PROCESSING, POROSITY, COGNAC

Введение. Производство коньяка имеет свою специфику и занимает особое положение в алкогольной промышленности во всех странах с развитым виноградарством и виноделием. Отличительные черты этого напитка 
Плодоводство и виноградарство Юга России № 60(6), 2019 г.

формируются за счет почвенно-климатических условий возделывания винограда, используемых агротехнических приемов и технологических особенностей производства продукции [1-5].

Необходимым технологическим фактором в производстве высококачественных коньяков является древесина дуба. При увеличивающемся спросе на продукцию высокого качества встает вопрос дефицита дорогостоящей дубовой тары, использование которой предусмотрено традиционной технологией. При этом запасы высококачественной древесины для производства винодельческих бочек неуклонно снижаются [6].

Разработкой технологически гибких способов подготовки древесины дуба для выдержки коньячных дистиллятов занимались и продолжают заниматься как российские, так и зарубежные учёные [7-11]. Повышение эффективности использования древесины дуба может быть достигнуто путем реализации приемов активации, основанных на биокатализе, так как процессы, протекающие при естественной сушке древесины, имеют биохимическую основу [12-14].

В настоящее время активацию процесса созревания дубовой клепки традиционно осуществляют с использованием физических и химических способов. Процесс биохимической активации дубовой древесины, используемой в коньячном производстве, остаётся мало изученным. Таким образом, исследования, направленные на совершенствование технологии производства российских коньяков посредством использования приемов биохимической активации древесины дуба, являются актуальными.

Согласно правилам по производству винодельческой продукции [15] разрешенными способами подготовки дубовой древесины к выдержке являются термическая и кислотно-щелочная обработка клепки. В целях установления влияния способа обработки на свойства дубовой древесины нами был проведен сравнительный анализ способов предварительной подготовки дубовой клепки к выдержке: химического, термического и биохимического [16]. 
Объекты и методы исследований. Объектом исследований являлась дубовая клепка из древесины кавказского и лемузенского дуба. Термическую обработку древесины проводили путем нагревания дубовых кусочков при температуре $140{ }^{\circ} \mathrm{C}$ в течение 45 часов [17]. Химическую обработку проводили 0,3 \%-ми растворами соляной кислоты $(\mathrm{HCl})$ и гидроокиси натрия $(\mathrm{NaOH})[18]$. Биохимический способ заключался в обработке древесины суспензией ферментного препарата, обладающего целлюлолитической активностью. При выборе дозировок руководствовались рекомендациями по обработке мезги в винодельческом производстве [19].

При определении адсорбционной емкости активированной древесины адсорбцию уксусной кислоты осуществляли из раствора с концентрацией 0,5 моль/дм ${ }^{3}[20]$. Образцы не обработанной и обработанной клёпки вносили в раствор из расчета гиромодуля 1:10 на 40 мин, взбалтывая содержимое колб каждые 5 мин. По истечении 40 мин абсорбции определяли концентрацию уксусной кислоты в растворах методом капиллярного электрофореза на приборе Капель 105 [21].

Обсуждение результатов. Известно, что при обработке древесины происходит растворение некоторой части компонентов клеточных стенок, которое приводит к увеличению объема полостей клеток, и, как следствие, к увеличению пористости [22]. Повышение пористости и увеличение проницаемости клеточной стенки волокон древесины обеспечивает более полное извлечение лигнина, дубильных веществ и ароматических альдегидов дистиллятом в процессе выдержки. При этом, соответственно, изменяются механические свойства древесины.

Показатель пористости древесины позволяет оценить суммарный объем капилляров, доступных для полярных жидкостей [23]. Одним из показателей изменения пористости является значение адсорбционной ёмкости активированной древесины [24]. В целях установления влияния способа активации древесины перед выдержкой на изменение ее пористости нами 
Плодоводство и виноградарство Юга России № 60(6), 2019 г.

были проведены исследования по определению адсорбции уксусной кислоты на обработанной различными способами дубовой клепке.

Анализ экспериментальных данных показывает, что при обработке древесины кислотным, щелочным, термическим и биохимическим способами сорбция уксусной кислоты на поверхности древесины увеличивается в несколько раз (рис. 1). Согласно полученным данным, адсорбция уксусной кислоты на поверхности необработанного кавказского дуба составляла 1,8 ммоль/дм ${ }^{3}$, при этом для лемузенского дуба эта величина 0,5 ммоль/дм ${ }^{3}$, что может быть связано с особенностями анатомического строения древесины данных видов дуба.

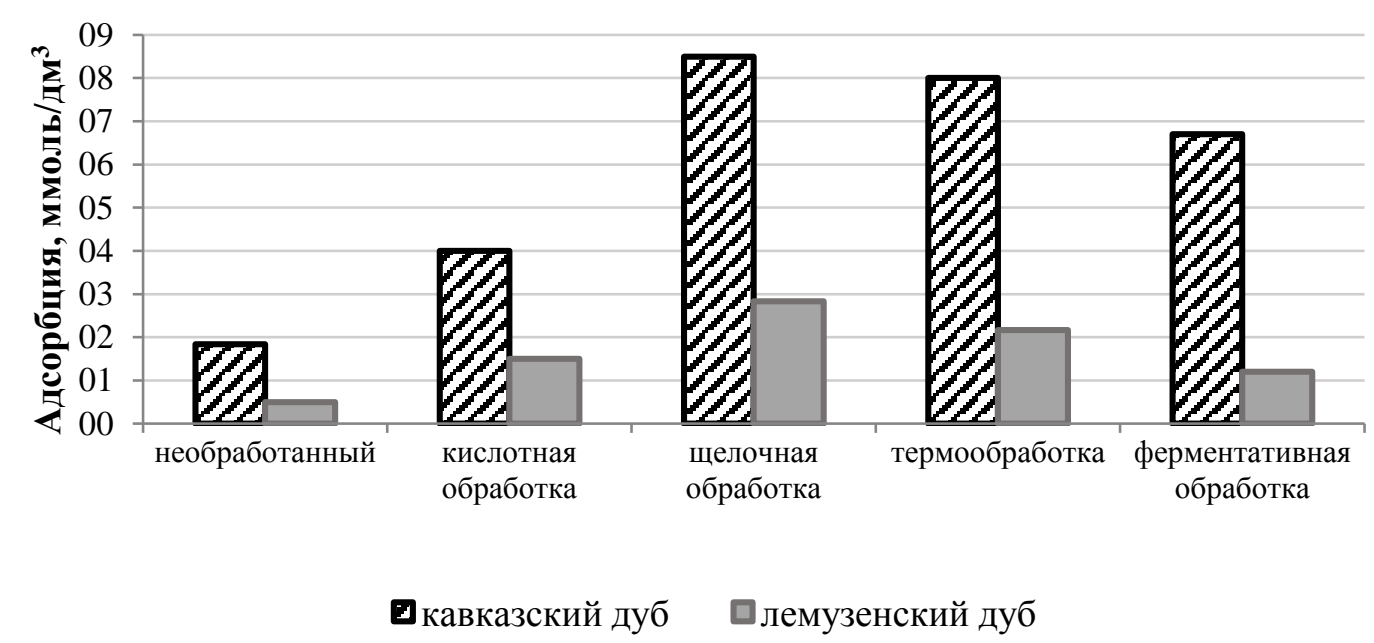

Рис. 1. Величина адсорбции уксусной кислоты на поверхности древесины, обработанной различными способами

При исследовании влияния химической активации древесины на величину сорбции уксусной кислоты было установлено, что при обработке кавказского дуба этот показатель увеличивается в 2,2-4,7 раза по сравнению с необработанной древесиной. В результате обработки лемузенского дуба адсорбция уксусной кислоты увеличилась в 3-5,6 раза. Следует отметить, что обработка древесины раствором щелочи приводит к увеличению сорбционной емкости древесины в 2 раза по сравнению с кислотной обработкой. 
Термообработка древесины также характеризовалась увеличением величины адсорбции на поверхности древесины. При обработке кавказского дуба эта величина составляла 8,0 ммоль/дм³ ${ }^{3}$ лемузенского - 2,2 ммоль/дм².

В результате ферментативной обработки древесины величина адсорбции уксусной кислоты составляла 6,7 ммоль/дм³ ${ }^{3}$ на поверхности кавказского дуба и 1,2 ммоль/дм³ - на поверхности лемузенского. Следует отметить, что адсорбция при ферментативной активации древесины была слабее, чем при термообработке и щелочной активации.

При исследовании динамики величины адсорбции на поверхности активированной древесины в зависимости от продолжительности обработки ферментными препаратами была отмечена устойчивая тенденция к увеличению адсорбционной способности древесины при возрастании времени воздействия на нее ферментного препарата (рис. 2).

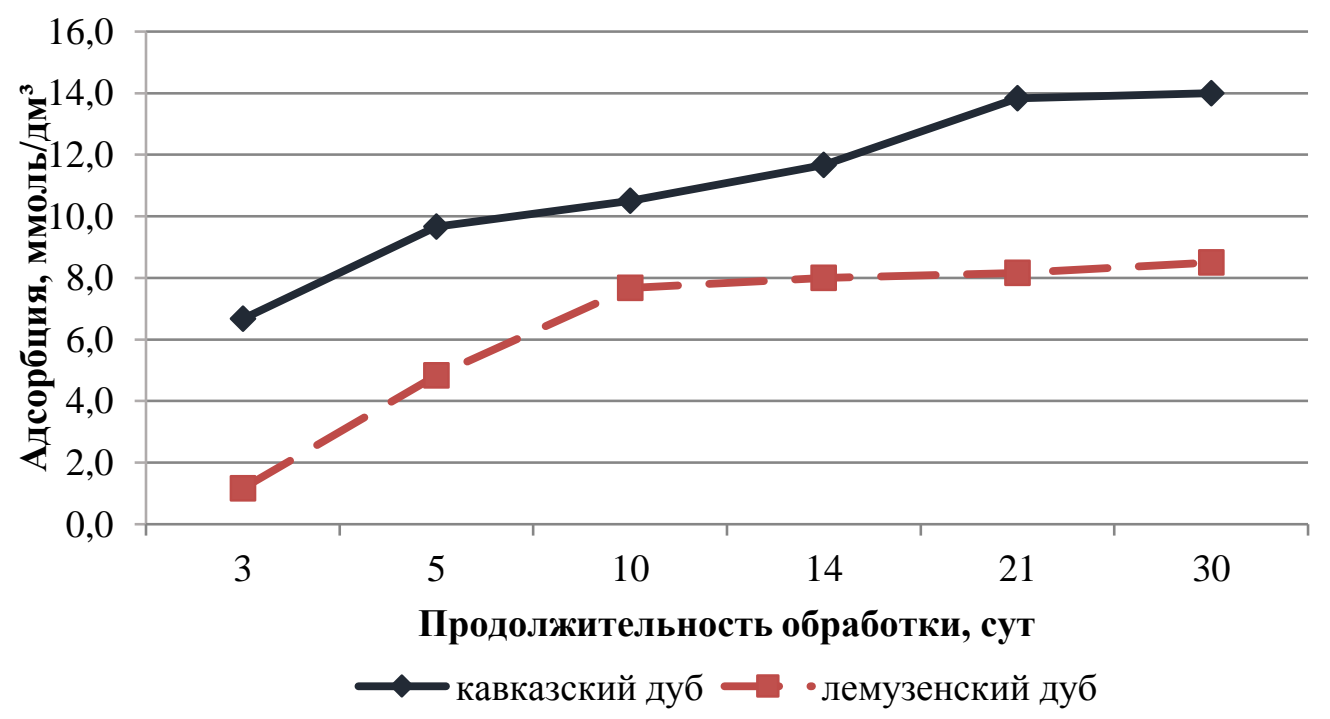

Рис. 2. Динамика адсорбции уксусной кислоты на поверхности древесины при биохимической активации

Экспериментально установлено, что на поверхности древесины лемузенского дуба адсорбция уксусной кислоты имеет более низкий уровень, чем на поверхности кавказского дуба независимо от продолжительности воздействия ферментами. При активации древесины кавказского дуба ферментным препаратом от 3 до 30 дней величина адсорбции увеличилась 
от 6,7 до 14,0 ммоль/дм³ ского дуба этот показатель изменялся в интервале от 1,2 до 8,5 ммоль/дм³

Таким образом, биохимическая обработка древесины ферментными препаратами оказывает значительное влияние на изменение пористости дубовой клепки. Экспериментально установлено, что адсорбционная способность древесины, а следовательно и пористость, при активации увеличивается в 2,4-3,7 раза в зависимости от вида дуба за счет того, что при обработке дубовой клепки комплексными ферментными препаратами, обладающими целлюлолитической, $\beta$-полигалактуроназной и $\beta$-гликозидазной активностью, происходит ускорение процесса старения древесины дуба в результате разрушения водородных, фенилгликозидных и простых эфирных связей между лигнином и гемицеллюлозами, а также вследствие гидролитического расщепления клетчатки. Необходимо отметить, что продолжительность обработки древесины ферментными препаратами прямо пропорциональна увеличению величины адсорбции уксусной кислоты на ее поверхности, а, следовательно, и пористости.

Bblвodbl. Проведенные исследования показали, что к наиболее значительным изменениям структуры древесины дуба приводит щелочная обработка, увеличивая адсорбционную емкость (пористость) в 4,7-5,6 раза. При термической обработке древесины величина адсорбции на ее поверхности увеличивается в 4,4 раза, а при биохимической - в 2,4-3,7 раза по сравнению с необработанной. Кислотная обработка дубовой древесины характеризовалась самой низкой величиной адсорбции среди всех рассматриваемых обработок, увеличивая величину адсорбции всего в 2,2-3,0 раза.

\section{Литература}

1. Серпуховитина К.А., Аванесьянц Р.В. Природный и сортовой потенциал производства коньяков в России // Виноделие и виноградарство. № 6. 2011. С. 4-5.

2. Соколин Р.А., Христюк В.Т. Влияние почвенно-климатических условий выращивания коньячных сортов винограда и определение зональной специализации коньячного производства // Политематический сетевой электронный научный журнал Кубанского государственного аграрного университета. 2016. № 120. С. 1392-1402. 
3. Benedetti F. Synthesis of all stereoisomers of cognac lactones via microbial reduction and enzymatic resolution strategies/Benedetti F., Forzato C., Nitti P., Pitacco G., Valentin E., Vicario M.-Tetrahedron: Asymmetry. 2001. T. 12. № 3. C. 505-511.

4. Song L. Cognac consumption: a comparative study on American and Chinese consumers/Song L., Wei Y., Bergiel B.J.-Wine Economics and Policy.2018.V.7. №1. C 24-34.

5. Panakhov T.M. Prospects of using oak wood integrated processing products in winemaking, dealing wish shortcomings on the base of implementing oak wood derivative productsIndian Journal of Science and Technology. 2016. T. 9. № 22. C. 95553.

6. Хорькова Ю. Сырье и готовая алкогольная продукция. Основные тренды // Индустрия напитков. 2011. № 3. С. 32-35.

7. Оганесянц Л.А. Дуб и виноделие. М.: Пищевая промышленость. 1998. 256 с.

8. Егоров И.А., Родопуло А.К. Химия и биохимия коньячного производства. М.: Агропромиздат, $1998.193 \mathrm{c.}$

9. Скурихин И.М. Химия коньяка и бренди. М: ДеЛи принт. 2005. 296 с.

10. Puech J.-L. Characteristics of oak wood and biochemical aspects of Armagnac aging. - Americ. J. Enol. And Viticult. 2004. 35. № 6. pp.77-81.

11. Kirk F. Factor involved in the regulation of a ligninase activity in Phanerochaete chrysesporium. - Appl. and Environ. Microbial. 2005.V. 49. № 2. P. 229-304.

12. Sarvarova N.N. Application of chramotographic metods to the determination of cognac quality indicators / Sarvarova N.N., Cherkashina Yu.A., Evgen'Ev M.I./ Journal of Analytical Chemistry. 2011. T. 66. № 12. C. 1190-1195.

13. Pisarnitskii A.F. Study of alcohol-soluble lignin in cognac spirits / Pisarnitskii A.F., Askenderov K.A.// Applied Biochemistry and Microbiology. 2008. T. 44. № 6. C. 652-656.

14. Vivas N. Manuel de tonnellerie à l'usage des utilisateurs de futaille / Vivas N. // Editions Féret. - Bordeaux: 2002. - pp. 207

15. Сборник основных правил, технологических инструкций и нормативных материалов по производству винодельческой продукции / Под общ. ред. Н.Г. Саришвили // Москва: Пищепромиздат. 1998. 244 с.

16. Резниченко К.В., Оселедцева И.В., Гугучкина Т.И. Биологическая активация дубовой древесины в коньячном производстве // Виноделие и виноградарство № 5. 2012. C. 30-33.

17. Кухно А.И. Оптимальные режимы обработки дубовой древесины в производстве крепких спиртных напитков. // Известия вузов. Пищевая технология, № 5-6. 1995. C. $48-49$

18. Оганесянц Л.А., Джанаева О.В. Определение оптимальных параметров обработки древесины дуба для использования в производстве крепких спиртных напитков // Хранение и переработка сельскохозяйственного сырья. 2004. № 4, С. 40-41

19. Технологические правила виноделия. В 2 т. / Под ред. Г.Г. Валуйко и В.А. Загоруйко. Симферополь: Таврида, 2006. Т1: Общие положения. Тихие вина. С. 217.

20. Лабораторные работы и задачи по коллоидной химии / Под ред. Ю.Г. Фролова. М.: Химия.1996. 216 с.

21. Методика М 04-47-2012 Определение органических кислот в винодельческой, соковой, алкогольной, безалкогольной, слабоалкогольной и пивоваренной продукции. $16 \mathrm{c.}$

22. Шамаев В.А. Модификация древесины. М.: Экология, 1991. 128 с.

23. Уголев Б.Н. Древесиноведение с основами лесного товароведения. М.: Лесная промышленность, 1996. 368 с.

24. Новикова Л.А., Бельчинская Л.И., Ресснер Ф. Адсорбция уксусной кислоты на природном и активированном щелочью монтмориллоните/ // Сорбционные и хроматографические процессы. 2007.Т. 7. Вып. 5. С.741-745

\section{References}

1. Serpuhovitina K.A., Avanes'yanc R.V. Prirodnyj i sortovoj potencial proizvodstva kon'yakov v Rossii // Vinodelie i vinogradarstvo. № 6. 2011. S. 4-5. 
2. Sokolin R.A., Hristyuk V.T. Vliyanie pochvenno-klimaticheskih uslovij vyrashchivaniya kon'yachnyh sortov vinograda i opredelenie zonal'noj specializacii kon'yachnogo proizvodstva // Politematicheskij setevoj elektronnyj nauchnyj zhurnal Kubanskogo gosudarstvennogo agrarnogo universiteta. 2016. № 120. S. 1392-1402.

3. Benedetti F. Synthesis of all stereoisomers of cognac lactones via microbial reduction and enzymatic resolution strategies/Benedetti F., Forzato C., Nitti P., Pitacco G., Valentin E., Vicario M.-Tetrahedron: Asymmetry. 2001. T. 12. № 3. S. 505-511.

4. Song L. Cognac consumption: a comparative study on American and Chinese consumers/Song L., Wei Y., Bergiel B.J.-Wine Economics and Policy.2018.V.7. №1. S 24-34.

5. Panakhov T.M. Prospects of using oak wood integrated processing products in winemaking, dealing wish shortcomings on the base of implementing oak wood derivative productsIndian Journal of Science and Technology. 2016. T. 9. № 22. S. 95553.

6. Hor'kova Yu. Syr'e i gotovaya alkogol'naya produkciya. Osnovnye trendy // Industriya napitkov. 2011. № 3. S. 32-35.

7. Oganesyanc L.A. Dub i vinodelie. M.: Pishchevaya promyshlenost'. 1998. 256 s.

8. Egorov I.A., Rodopulo A.K. Himiya i biohimiya kon'yachnogo proizvodstva. M.: Agropromizdat, $1998.193 \mathrm{~s}$.

9. Skurihin I.M. Himiya kon'yaka i brendi. M: DeLi print. 2005. $296 \mathrm{~s}$.

10. Puech J.-L. Characteristics of oak wood and biochemical aspects of Armagnac aging. - Americ. J. Enol. And Viticult. 2004. 35. № 6. pp.77-81.

11. Kirk F. Factor involved in the regulation of a ligninase activity in Phanerochaete chrysesporium. - Appl. and Environ. Microbial. 2005.V. 49. № 2. R. 229-304.

12. Sarvarova N.N. Application of chramotographic metods to the determination of cognac quality indicators / Sarvarova N.N., Cherkashina Yu.A., Evgenl'Ev M.I./ Journal of Analytical Chemistry. 2011. T. 66. № 12. S. 1190-1195.

13. Pisarnitskii A.F. Study of alcohol-soluble lignin in cognac spirits / Pisarnitskii A.F., Askenderov K.A.// Applied Biochemistry and Microbiology. 2008. T. 44. № 6. S. 652-656.

14. Vivas N. Manuel de tonnellerie à l'usage des utilisateurs de futaille / Vivas N. // Editions Féret. - Bordeaux: 2002. - pp. 207

15. Sbornik osnovnyh pravil, tekhnologicheskih instrukcij i normativnyh materialov po proizvodstvu vinodel'cheskoj produkcii / Pod obshch. red. N.G. Sarishvili // Moskva: Pishchepromizdat. 1998. 244 s.

16. Reznichenko K.V., Oseledceva I.V., Guguchkina T.I. Biologicheskaya aktivaciya dubovoj drevesiny v kon'yachnom proizvodstve // Vinodelie i vinogradarstvo № 5. 2012. S. 30-33.

17. Kuhno A.I. Optimal'nye rezhimy obrabotki dubovoj drevesiny v proizvodstve krepkih spirtnyh napitkov. // Izvestiya vuzov. Pishchevaya tekhnologiya, № 5-6. 1995. S. 48-49

18. Oganesyanc L.A., Dzhanaeva O.V. Opredelenie optimal'nyh parametrov obrabotki drevesiny duba dlya ispol'zovaniya $\mathrm{v}$ proizvodstve krepkih spirtnyh napitkov // Hranenie i pererabotka sel'skohozyajstvennogo syr'ya. 2004. № 4, S. 40-41

19. Tekhnologicheskie pravila vinodeliya. V 2 t. / Pod red. G.G. Valujko i V.A. Zagorujko. Simferopol': Tavrida, 2006. T1: Obshchie polozheniya. Tihie vina. S. 217.

20. Laboratornye raboty i zadachi po kolloidnoj himii / Pod red. Yu.G. Frolova. M.: Himiya.1996. $216 \mathrm{~s}$.

21. Metodika M 04-47-2012 Opredelenie organicheskih kislot v vinodel'cheskoj, sokovoj, alkogol'noj, bezalkogol'noj, slaboalkogol'noj i pivovarennoj produkcii. $16 \mathrm{~s}$.

22. Shamaev V.A. Modifikaciya drevesiny. M.: Ekologiya, 1991. 128 s.

23. Ugolev B.N. Drevesinovedenie s osnovami lesnogo tovarovedeniya. M.: Lesnaya promyshlennost', 1996. $368 \mathrm{~s}$.

24. Novikova L.A., Bel'chinskaya L.I., Ressner F. Adsorbciya uksusnoj kisloty na prirodnom i aktivirovannom shcheloch'yu montmorillonite/ // Sorbcionnye i hromatograficheskie processy. 2007.T. 7. Vyp. 5. S.741-745 